\title{
Nekatere značilnosti doživljanja sebe pri osebah s shizofrenijo in pri tistih po nezgodni poškodbi hrbtenjače
}

\author{
Barbara Horvat* \\ Univerzitetni rehabilitacijski inštitut Republike Slovenije - Soča
}

\begin{abstract}
Povzetek: Doživljanje sebe je sinonim za besedno zvezo "kdo sem", prek katere vsak izmed nas izraža svojo skladnost $\mathrm{s}$ socialnimi normami in $\mathrm{z}$ družbenim okoljem. Poteka na različnih področjih posameznikovega življenja in $\mathrm{v}$ povezavi z različnimi socialnimi vlogami. Ključnega pomena je občutek kontinuitete skozi različna življenjska obdobja. Stresni dogodki, tudi posameznikove težje poškodbe in bolezni, omajejo in spremenijo doživljanje samega sebe. Prav gotovo lahko v to kategorijo umestimo tudi stanja, značilna za shizofrenijo, in spremembe, ki botrujejo nezgodnim poškodbam hrbtenjače. Rezultati različnih študij nakazujejo pri osebah s shizofrenijo prisotnost razpršene identitete; pri osebah po nezgodni poškodbi hrbtenjače je ključna prizadetost telesne komponente ter s tem telesne samopodobe. Osnovni problem naše študije je predstavljala primerjava značilnosti doživljanja sebe pri osebah s shizofrenijo in tistih po nezgodni poškodbi hrbtenjače. Predpostavili smo pomembne razlike v ocenah različnih področjih doživljanja sebe (predvsem na področju socialne in telesne samopodobe), v smislu nižjih ocen v primerjalnih skupinah. V študijo je bilo vključenih 90 udeleženk in udeležencev, po 30 iz vsake skupine (osebe s shizofrenijo, osebe po nezgodni poškodbi hrbtenjače in kontrolna skupina oseb brez prisotnih znakov patologije), ki so izpolnili vprašalnik Tennesseejska lestvica koncepta sebe ter semantični diferencial Ocena sebe. Rezultati kažejo, da je pri osebah s shizofrenijo vrednotenje sebe na splošno nizko (celo negativno), pri osebah po nezgodni poškodbi hrbtenjače pa idealizirano, pod vplivom obrambno-varovalnega vedenja, ki omogoča potrjevanje pozitivne samopodobe. Menimo, da so izsledki študije pomembni predvsem za usmerjanje psihološkega dela s predstavniki obeh populacij. Pri osebah s shizofrenijo bi bilo zaželeno še dodatno poudariti pomen zaznavanja sebe na različnih področjih, osebe po nezgodni poškodbi hrbtenjače pa bi morali usmerjati k nadomeščanju manj zrelih oblik obrambno-varovalnega vedenja z bolj zrelimi ter s tem k realnejšemu doživljanju sebe.
\end{abstract}

Ključne besede: doživljanje sebe, samopodoba, shizofrenija, nezgodne poškodbe hrbtenjače

\section{Some aspects of self-experiece in people with schizophrenia and those after spinal cord injury}

\author{
Barbara Horvat* \\ University Rehabilitation Institute, Ljubljana, Slovenia
}

\begin{abstract}
Self-experiencing is synonymous with the phrase "who am I". Each of us expresses his compliance with social norms and social environment through it. It takes place in different areas of a person's life and in conjunction with different social roles. The sense of continuity throughout the different periods of life is very important. Stressful events, also difficult injuries and diseases, upset and change the experience of oneself. Schizophrenia and spinal cord injuries can be classified in this category. The results of various studies suggest that in people with schizophrenia diffuse identity is present; in subjects after spinal-cord injury the physical disability is crucial and importantly affects the physical self-image. The main problem of our study was to compare the characteristics of self-experience in people with schizophrenia and those after spinal cord injury. We assumed significant differences in self-experience on different subscales (mainly in the field of social and physical self concept) between the two comparison groups. 90 participants were involved in the study, 30 in each group (people with schizophrenia, people after spinal cord injury and a control group of people without any present signs of pathology). We applied the Tennessee self-concept scale and the semantic differential assessment of Self. The results showed general low (or even negative) self evaluations in the group of people with schizophrenia, while in the group of people after spinal-cord injury idealization was present. This group of people is under a great influence of defensive mechanisms, which allow the validation of a positive self concept. Important derogations were also shown on some subscales. We believe that the results of the study are especially important in the psychological work with representatives of the two populations. People with schizophrenia should be introduced with the meaning of self-experiencing in different areas, while people after spinal cord injury should be taught how to replace defensive mechanisms with constructive coping strategies which help to experience ourselves objectively.
\end{abstract}

Key words: self-experience, self concept, schizophrenia, spinal-cord injuries

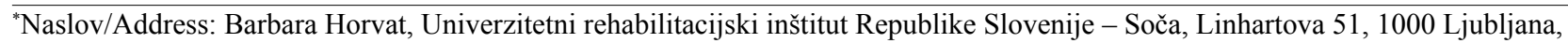
e-mail: barbara.horvat@ir-rs.si
} 
Ljudje smo živa bitja, sposobna prepoznavati različna področja sebe, se jih zavedati in o njih poročati tudi drugim. Lahko rečemo, da nam je dana posebna kvaliteta, ki jo lahko poimenujemo kot doživljanje samega sebe. Predstavlja sinonim za besedno zvezo "kdo sem", prek katere vsak izmed nas izraža svojo skladnost s socialnimi normami in z družbenim okoljem (Sheldon, Renwick in Yoshida, 2011), hkrati pa nam omogoča predstavo o samem sebi, o tem, kaj sodi k nam in kaj ne, kaj pričakujemo o samem sebi, kaj je del nas kot posameznikov (RakovecFelser, 2009). Z vidika psihoanalitičnih teorij pomeni doživljanje sebe rezultat dolgotrajnejšega procesa zorenja psihičnega aparata, ki vključuje predvsem procese identifikacije $\mathrm{z}$ drugimi osebami (Benedik, 2000b). Koncept doživljanja sebe je torej societalen (Hughes, 2002; Sheldon idr., 2011) in poteka na različnih področjih posameznikovega življenja ter $\mathrm{v}$ povezavi $\mathrm{z}$ različnimi socialnimi vlogami. Takoj ko se že prej omenjena osebna doživljanja sebe spojijo in integrirajo s posameznikovim zaznavanjem sprejemanja samega sebe s strani drugih, doživljanje sebe preraste v samopodobo (Drench, 1994).

Splošno samopodobo lahko opredelimo kot interakcijo, presek telesnih, čustvenih ter kognitivnih komponent Selfa (McConnell, 2011; Taleporos in McCabe, 2001; v: Sheldon idr. 2011). V slovenskem prostoru je zelo znana opredelitev, ki jo s povzemanjem in združevanjem različnih definicij podaja D. Kobal Grum (2000), ki samopodobo opredeljuje kot organizirano celoto lastnosti, potez, občutij, podob, stališč, sposobnosti in drugih psihičnih vsebin, za katere je značilno, da: (1) jih posameznik v različnih stopnjah razvoja in v različnih situacijah pripisuje samemu sebi; (2) tvorijo referenčni okvir, s katerim posameznik uravnava in usmerja svoje ravnanje; (3) so v tesni povezavi z obstoječim vrednotnim sistemom posameznika ter $\mathrm{z}$ vrednotnim sistemom ožjega in širšega družbenega okolja; (4) so pod nenehnim vplivom delovanja obrambnih mehanizmov in predstavljajo nekakšne membrane med nezavednim in zavestnim, ki prepušča le tiste vsebine, ki so sprejemljive za posameznikov jaz.

Skozi različna časovna obdobja so pri vzdrževanju samopodobe ključnega pomena tudi občutki kontinuitete oz. istosti sebe. Le-te utrjuje tudi priznanje okolice, da doživlja posameznika kot istega $\mathrm{v}$ različnih življenjskih obdobjih in situacijah (Erickson, 1963; v: Benedik, 2000a, 2000b). Življenje pa ne poteka vselej po naših predvidevanjih, temveč lahko ubere povsem svojo pot, ki je ne znamo predvideti. Nepričakovani dogodki in situacije zahtevajo prilagoditve in celotno ter dolgotrajnejšo osebnostno vpetost $\mathrm{v}$ stresne dogodke. Stresni dogodki višje intenzitete so tisti, ki lahko prekinejo kontinuiranost samopodobe in sprožijo njeno reorganizacijo. Na vrhu najintenzivnejših stresorjev se po sloviti raziskavi Holmesa in Raha (1967; v: Amiram in Selzer, 1975) nahajajo posameznikove težje poškodbe in bolezni. $\mathrm{V}$ to kategorijo umeščamo tudi stanja, značilna za shizofrenijo, in spremembe, ki botrujejo nezgodnim poškodbam hrbtenjače, na katerih temelji naša raziskava.

Čeprav sta shizofrenija in poškodbe hrbtenjače vezane na motnje v delovanju osrednjega živčnega sistema, gre za okvaro dveh različnih organov in s tem za različne posledice, ki se kažejo v posameznikovem vsakdanjem življenju in otežujejo njegovo delovanje. Pri obeh stanjih so spremembe večinoma trajne.

Shizofrenija je težja duševna motnja, ki pomembno oškoduje posameznikovo celostno delovanje v vsakdanjem življenju, saj prizadene miselne procese, čustvovanje in vedenje. Simptomi shizofrenije otežujejo vpetost v družbeno okolje ter pomembno osiromašijo vzpostavljanje in vzdrževanje medosebnih odnosov (Combs, Mueser in Gutierrez, 2012). Sočasno so pridružene spremembe zmožnosti mentalnega delovanja, ki se zelo pogosto kažejo v okvarjenih izvršitvenih funkcijah (Groznik, 1999; Yanos, Roe in Lysaker, 2010; Walker in Tessner, 2008), negativni simptomi pa so izhodišče za znižano motivacijo in negativno čustvovanje, ki pomembno zvišuje tveganje za samomor. Pomembne posledice nastopijo tudi pri posameznikih po nezgodni poškodbi hrbtenjače in prav tako znižujejo kakovost njegovega življenja. V ospredju so zmanjšane zmožnosti delovanja na področju telesnega funkcioniranja. Izstopajo okvare motorike in senzoričnega zaznavanja; prisotne so težave izločanja, težave $\mathrm{z}$ dihanjem in neuravnovešenim krvnim tlakom (npr. Frank, Rosenthal in Caplan, 2009). Tako kot pri osebah s shizofrenijo so tudi v tej skupini posameznikov prisotne kognitivne spremembe predvsem v smeri zmanjšane pozornosti, ki naj bi bila povezana $\mathrm{s}$ premorbidno pomembno zvišano impulzivnostjo (Murray idr., 2007). Po izsledkih nekaterih študij (Anderson, 2004; Wortman in Silver, 1989) pa so ključnega pomena tudi težave na področju čustvovanja, saj prav zaradi soočanja s svojo novo podobo in žalovanjem za starim Selfom poraste tveganje za razvoj depresivne simptomatike in anksioznosti.

Ugotovitve nekaterih študij nadalje kažejo (npr. Conway, 2005; Fitts in Warren, 1996; Yanos idr., 2010) na pomembne razlike $\mathrm{v}$ doživljanju sebe pri osebah $\mathrm{s}$ shizofrenijo in zdravimi osebami. Ti bolniki imajo o različnih vidikih sebe (telesni, socialni, akademski, osebnostni in moralno etični Self) namreč bolj negativno podobo. Raffard idr. (2009) pišejo, da je le-ta posledica "zmedenega" doživljanja sebe, za katero sta trenutno na voljo dve razlagi. Prva se nanaša na samoopredeljujoče spomine (angl. self-defining memories; Howe, Courage in Edison, 2003; Raffard idr., 2009), ki nam pomagajo ustvarjati predstavo o sebi, hkrati pa nam omogočajo, da lahko sebe predstavimo tudi drugim (Miller Smedema, Bakken-Gillen in Dalton, 2009; Singer, 2005, v Raffard idr., 2009). Nekoliko starejša, a še zmeraj prav tako veljavna razlaga pa se opira na značilnosti psihotične organizacije strukture osebnosti oseb s shizofrenijo (Kernberg, 1986, v Benedik 2000a). Po tej teoriji pride pri osebah $\mathrm{s}$ shizofrenijo do motenj $\mathrm{v}$ delovanju ega, to je v delu psihičnega aparata, ki je mediator med osebo in resničnostjo. Občutek kontinuiranosti sebe in lastne vloge je s tem prekinjen, posameznik pa začne poročati o zlomu $\mathrm{V}$ občutku identitete sebe ter se dojema kot popolnoma drugo osebo (Smrdu, 2013). Bleuler (1911, v Raffard idr., 2009) je kot ključno posledico motene kontinuitete navajal težave 
pri vzpostavljanju smiselnih povezav med lastnim Selfom ter drugimi, kar pa je ključnega pomena pri vzpostavljanju in ohranjanju samopodobe, ki poteka v veliki meri tudi prek obrambnih mehanizmov pozunanjenja in projekcije (Penn idr., 1997, v Benedik, 2001; Jaramillo, Fuentes in Ruiz, 2009). Bentall, Kinderman in Kaney (1994) razlagajo obrambne mehanizme kot poskus odpravljanja neskladja med reprezentacijami sebe in Self ideala oz. kot odgovor na latentno negativno shemo Selfa, ki jo imajo ti bolniki.

Tako kot pri osebah s shizofrenijo je tudi pri osebah po nezgodni poškodbi hrbtenjače vzpostavitev samopodobe vezana na avtobiografske spomine in nenadno prekinitev kontinuitete doživljanja sebe, ki nastane kot posledica nesreče (Richards, Kewman, Richardson in Kennedy, 2010). Vsak upad ali izguba telesnih sposobnosti namreč poseže v zavest oz. predstavo o lastnem telesu, oblikovano s sprotnimi notranjimi in zunanjimi čutnimi izkušnjami, ki se povezujejo s spominskimi predstavami iz prejšnjih izkušenj in vednosti o telesu (Brejc, 2004; Sheldon idr., 2011). Tovrstno razlago še posebej podpirata Taleporos in McCabe (2002), ki navajata, da je konstruiranje samopodobe socialni konstrukt, saj naj bi proces vzpostavljanja samopodobe pri osebah po poškodbi hrbtenjače potekal skladno s postulati njunega socialnega modela sprejemanja invalidnosti. Proces oblikovanja samopodobe po nezgodni poškodbi hrbtenjače naj bi potekal skladno s predpostavkami vsaj enega izmed treh modelov spoprijemanja: (1) prvi model predstavlja proces žalovanja, (2) drugi simbolizira razvojno teorijo, (3) tretji pa je model primerjave Selfa pred in po poškodbi. Vse osebe po nezgodni poškodbi hrbtenjače skušajo svojo novo podobo sprejeti skozi proces žalovanja, ki sovpada s splošnim žalovanjem in vključuje pet korakov: šok in zanikanje, jezo, barantanje, depresivno simptomatiko ter sprejemanje (Westie, 1987). Vsi posamezniki ne gredo skozi vse faze v enakem vrstnem redu. Včasih se lahko v določeni fazi znajdejo večkrat ali pa se vračajo na katero od predhodnih stopenj. Kot drugo omenjamo razvojno teorijo spoprijemanja, ki je izpeljana iz Ericksonovega modela (Westie, 1987) vseživljenjskega psihosocialnega razvoja. Po tej teoriji travma, ki nastane kot posledica poškodbe hrbtenjače, ter omejitve posameznikovih zmožnosti delovanja sproži regresijo k pridobivanju moči, ki naj bi si jih posameznik pridobil že kot otrok. Na nek način preide poškodovani posameznik na razvojno raven otroka. Najprej mora poškodovani posameznik vzpostaviti bazično zaupanje in premagati razočaranje nad življenjem, sledi pridobivanje avtonomije in za tem podajanje lastne iniciative. Pacienti po nezgodni poškodbi hrbtenjače morajo tako $\mathrm{z}$ vidika telesne kondicije kot čustvenega stanja ponovno preiti $v$ fazo dojenčka in otroka, saj je kar nekaj primerov, ko niso zmožni govora, vse osebe pa je v začetni fazi takoj po poškodbi potrebno previjati, nekatere hraniti ter jih ponovno učiti ritma izločanja. Omenimo še zadnji, tj. tretji model, ki je znan kot model primerjave. Vezan je na posameznikov že omenjeni avtobiografski spomin in poteka ob obeh že omenjenih modelih, saj se dogaja primerjava premorbidnega Selfa $\mathrm{z}$ novim Selfom po poškodbi (Westie, 1987). Osrednja vloga pri oblikovanju nove samopodobe ter pri primerjavi med nekdanjim in trenutnim Selfom pripada telesu, ker ima (telo) osrednji vrednotni in čustveni pomen pri splošni samopodobi (Brejc, 2004). Vsaka sprememba v telesnem delovanju, ki je pomembna za osebnostno identiteto in samopodobo, ima vedno velik vrednotni pomen (Brejc, 2004; Chronister in Johnson, 2009; Horvat, 2012). Zato se lahko nekdo s prizadetostjo, ne glede na to, da lahko še marsikaj stori in v marsičem uživa, hitro in površno oceni, da je postal popolnoma nemočen "invalid" (Pollard in Kennedy, 2007). Lahko pa ga taka sprememba $\mathrm{V}$ sposobnostih spodbudi, da se začne potegovati za cilje, ki jih je do tedaj zapostavljal (Chau idr., 2008). Seveda pa so vrednote, povezane s telesom, $\mathrm{v}$ veliki meri odvisne tudi od odziva drugih ljudi na telesno podobo in zmogljivosti posameznika. Zato ima telesni Self močan socialni izvor in vsebino, posledica tega pa je, da se vlogi telesa kot dražljaja sebi in drugim v veliki meri pokrivata (Omolayo, 2009). V procesu spoprijemanja večina pacientov ne uspe sprejeti svojega novega telesnega stanja, zato pri njih začnejo delovati obrambni mehanizmi (predvsem zanikanje in kompenzacija), ki pomembno oblikujejo njihovo samopodobo, Realni Self pa močno približajo ali izenačijo z Želenim. V tem kontekstu so zanimivi izsledki ene izmed študij (Westie, 1987), v kateri so analizirali sanje 130-ih oseb po nezgodni poškodbi hrbtenjače; $75 \%$ jih leto dni po poškodbi sebe v sanjah ni videlo z vozičkom, ampak kot hodeče posameznike, kar nakazuje na delovanje obrambnih mehanizmov in nezmožnost vključevanja spremenjene telesne sheme v svojo samopodobo.

Osnovni problem naše študije predstavlja ugotavljanje značilnosti doživljanja sebe pri osebah s shizofrenijo in pri tistih po poškodbi hrbtenjače, ki se pojavijo kot posledica organskih sprememb dveh različnih področij (možgani in hrbtenjača) in se kažejo $v$ zmanjšani zmožnosti delovanja na vseh področjih življenja: telesno, duševno in socialno na nekoliko drugačen način in $\mathrm{z}$ različno intenziteto. Zaradi spremenjenega položaja $\mathrm{v}$ družbi se nenadoma spremenijo posameznikove socialne vloge, njegov status, kakovost življenja, prekine pa se tudi kontinuiteta doživljanja sebe (npr. Benedik, 2000a, 2000b; Combs idr., 2012; Sass in Parnas, 2003). Glede na to, da so spremembe $\mathrm{v}$ doživljanju sebe povezane $\mathrm{z}$ izboljšanjem posameznikove klinične slike (Zissi, Barry in Cichrane, 1998), predvidevamo, da je poznavanje značilnosti doživljanja sebe pri osebah po nezgodni poškodbi hrbtenjače in pri osebah s shizofrenijo ključno pri oblikovanju njihove rehabilitacije. Predvidevamo tudi, da obstajajo med primerjalnima skupinama in kontrolno skupino udeležencev, ki jo sestavljajo zdravi posamezniki brez predhodno diagnosticirane nevrološke, duševne ali druge kronične somatske bolezni, pomembne razlike $\mathrm{v}$ doživljanju sebe. Izhajajoč iz predstavljenega teoretičnega ozadja pričakujemo ključne razlike predvsem na področju doživljanja telesnega in socialnega selfa pri udeležencih po nezgodni poškodbi hrbtenjače in pri osebah s shizofrenijo 
(npr. Conway, 2005; Pollard in Kennedy, 2007; Richards idr., 2010, Sheldon idr., 2011; Walker in Tessner, 2008). Menimo, da bo pri osebah s shizofrenijo prisotno pomembno bolj negativno doživljanje celotnega sebe (npr. Conway, 2005; Fitts in Warren, 1996; Raffard idr., 2009; Yanos idr., 2010); pri osebah po nezgodni poškodbi hrbtenjače pa obrambno-varovalna naravnanost (npr. Pollard in Kennedy, 2007). Izsledki študije bodo lahko v pomoč predvsem strokovnim kadrom pri načrtovanju individualne psihosocialne rehabilitacije.

\section{Metoda}

\section{Udeleženci}

V študijo smo vključili tri skupine udeležencev. Primerjalni skupini sta bili dve - prvo so sestavljale osebe z zmanjšano zmožnostjo delovanja po nezgodnih poškodbah hrbtenjače, drugo pa osebe s shizofrenijo. Skupini udeležencev sta bili glede časa, ki je pretekel od nezgodne poškodbe hrbtenjače oz. prve psihotične epizode, dokaj izenačeni, saj je $\mathrm{v}$ skupini oseb po nezgodni poškodbi hrbtenjače znašal ta čas v povprečju 17,7 let $(S D=9,8)$, čas od prve psihotične epizode pri osebah s shizofrenijo pa 18,6 let $(S D=9,9)$. Udeležence smo pridobili v sodelovanju z nevladnimi društvi, ki se ukvarjajo z obravnavano problematiko: ŠENT in ALTRA (društvi za povezovanje ljudi s težavami $\mathrm{v}$ duševnem zdravju), društvo Vizija, Zveza paraplegikov, Društvo paraplegikov Ljubljanske pokrajine (društva, namenjena osebam po poškodbi hrbtenjače). Kontrolno skupino so sestavljali zdravi posamezniki, kar pomeni, da predhodno niso bili diagnosticirani za nevrološko, duševno ali drugo obliko kronične somatske bolezni. Vsi udeleženci, ki so bili vključeni v študijo, so bili seznanjeni $\mathrm{z}$ njenim namenom in so s podpisom obveščenega soglasja privolili v prostovoljno sodelovanje. V vsako skupino je bilo zajetih 30 udeležencev in udeleženk. Spodnja tabela prikazuje njihove osnovne demografske značilnosti.

Pri naboru vzorca smo upoštevali nekatere dodatne (vključitvene in izključitvene) kriterije. V skupino oseb s shizofrenijo smo zajeli posameznike s potrjeno diagnozo iz spektra shizofrenih motenj po ICD-10 (WHO, 1993), ki so bili trenutno $\mathrm{v}$ remisiji in je od zadnje hospitalizacije preteklo vsaj eno leto. Skupino udeležencev in udeleženk po nezgodni poškodbi hrbtenjače pa sestavljajo posamezniki s pridobljeno okvaro po nezgodi, ki se kaže v ohromelosti spodnjih udov. Od nesreče je moralo preteči vsaj eno leto. Iz nadaljnje obravnave smo izključili posameznike z morebitno sočasno zmanjšano zmožnostjo delovanja tako na telesnem kot tudi na duševnem področju, tiste $\mathrm{s}$ pridruženo obliko težje bolezni ali z nejasno diagnozo.

\section{Pripomočki}

Tennesseejska lestvica koncepta sebe (Tennessee Self-Concept Scale, TSCS-2; Fits in Warren, 1996). Tennesseejska lestvica koncepta sebe predstavlja široko uporaben in multidimenzionalen opis Selfa (Fits in Warren, 1996). V raziskavi smo uporabili prenovljeno verzijo vprašalnika, ki vsebuje 82 postavk ter preko njih ugotavljali posameznikovo doživljanje samega sebe s fizičnega, moralnega, socialnega, družinskega, akademskega in osebnostnega vidika ter sprejemljivost sebe in lastnega vedenja. Lestvica je bila predhodno že prevedena ter prirejena za slovenski prostor (Brejc in Stante, 1983). Glavne dimenzije lestvice, ki sočasno predstavljajo odvisne spremenljivke v pričujoči raziskavi, so sledeče:

- Nekonsistentnost: predstavlja rezultat variabilnosti od enega področja zaznavanja sebe do drugega. Visok rezultat pomeni udeleženčevo spremenljivost oz.

Tabela 1. Demografske značilnosti udeležencev in udeleženk v vsaki od skupin

\begin{tabular}{|c|c|c|c|c|c|c|}
\hline & \multicolumn{2}{|c|}{ osebe s shizofrenijo } & \multicolumn{2}{|c|}{ po poškodbi hrbtenjače } & \multicolumn{2}{|c|}{ kontrolna skupina } \\
\hline & $N$ & $\%$ & $N$ & $\%$ & $N$ & $\%$ \\
\hline \multicolumn{7}{|l|}{ spol } \\
\hline moški & 15 & 50,0 & 17 & 56,7 & 15 & 50,0 \\
\hline ženske & 15 & 50,0 & 13 & 43,3 & 15 & 50,0 \\
\hline \multicolumn{7}{|l|}{ starost } \\
\hline$M$ & 44,33 & & 42,07 & & 38,20 & \\
\hline$S D$ & 11,80 & & 11,16 & & 11,45 & \\
\hline \multicolumn{7}{|c|}{ leta izobrazbe } \\
\hline$M$ & 12,63 & & 12,80 & & 12,50 & \\
\hline$S D$ & 3,59 & & 1,69 & & 3,15 & \\
\hline \multicolumn{7}{|c|}{ zakonski stan } \\
\hline poročen & 3 & 10,0 & 11 & 36,7 & 15 & 50 \\
\hline v razmerju & 8 & 26,7 & 3 & 10,0 & 10 & 33,3 \\
\hline ovdovel & 2 & 6,7 & 0 & 0,0 & 1 & 3,3 \\
\hline samski & 13 & 43,3 & 14 & 46,7 & 4 & 13,3 \\
\hline razvezan & 4 & 13,3 & 2 & 6,7 & 0 & 0,0 \\
\hline
\end{tabular}


Tabela 2. Prikaz vsebine lestvice Ocena sebe

\begin{tabular}{rllllllll}
\hline optimistična & 1 & 2 & 3 & 4 & 5 & 6 & 7 & pesimistična \\
nesamostojna & 1 & 2 & 3 & 4 & 5 & 6 & 7 & samostojna \\
spretna & 1 & 2 & 3 & 4 & 5 & 6 & 7 & okorna \\
bolna & 1 & 2 & 3 & 4 & 5 & 6 & 7 & zdrava \\
inteligentna & 1 & 2 & 3 & 4 & 5 & 6 & 7 & neinteligentna \\
prilagodljiva & 1 & 2 & 3 & 4 & 5 & 6 & 7 & neprilagodljiva \\
mirna & 1 & 2 & 3 & 4 & 5 & 6 & 7 & živahna \\
družabna & 1 & 2 & 3 & 4 & 5 & 6 & 7 & nedružabna \\
zanimiva & 1 & 2 & 3 & 4 & 5 & 6 & 7 & enolična \\
fizično neprivlačna & 1 & 2 & 3 & 4 & 5 & 6 & 7 & fizično privlačna \\
sproščena & 1 & 2 & 3 & 4 & 5 & 6 & 7 & nesproščena \\
slaba & 1 & 2 & 3 & 4 & 5 & 6 & 7 & dobra \\
nespoštovana & 1 & 2 & 3 & 4 & 5 & 6 & 7 & spoštovana \\
vztrajna & 1 & 2 & 3 & 4 & 5 & 6 & 7 & nevztrajna \\
neprijazna & 1 & 2 & 3 & 4 & 5 & 6 & 7 & prijazna \\
\hline
\end{tabular}

neintegriranost posameznih delov Selfa.

- Socialna zaželenost: podajanje odgovorov, katerih vsebina je zaželena v širšem družbenem okolju.

- Samokritičnost: postavke predstavljajo nekoliko neugodne trditve, na katere večina ljudi odgovori pritrdilno (ocenijo, da postavka za njih drži). Posamezniki, ki večino trditev zanikajo, so nagnjeni $\mathrm{k}$ obrambno-varovalnemu vedenju in se trudijo, da bi o sebi podali dobro mnenje. Visoki rezultati običajno označujejo zdravo odprtost in sposobnost samokritike. Skrajno visoki rezultati pa utegnejo nakazovati preveliko stopnjo samokritičnosti.

- Distribucija odgovorov: predstavlja gotovost glede načina, kako posameznik vidi sebe. Visok rezultat odraža odločenost in gotovost glede stališč o samem sebi, ter nasprotno v primeru nizkih rezultatov.

- Identiteta: posameznik opisuje, kako vidi samega sebe. Visok rezultat pomeni zadovoljstvo s samim seboj.

- Zadovoljstvo: usmerjeno je na raven sprejemanja samega sebe. Visok rezultat predstavlja sprejemanje.

- Vedenje: lestvica meri posameznikovo zaznavanje lastnega vedenja in način delovanja. Visoki rezultati pomenijo sovpadanje med želenimi in dejanskimi dejanji.

- Telesna samopodoba: zajema posameznikovo telo, zdravstveno stanje, telesni videz, sposobnosti in spolnost.

- Moralna samopodoba: vključuje moralno-etični referenčni okvir, oceno sebe kot "dobre" oz. "slabe" osebe, posameznikov odnos do vere.

- Osebnostna samopodoba: je splošna mera osebnostne integracije in prilagojenosti, saj odraža posameznikov občutek osebne vrednosti, primernosti ter njegovo oceno lastne vrednosti izven njegovih odnosov $\mathrm{z}$ drugimi in izven njegovega telesa.

- Družinska samopodoba: nanaša se na posameznikovo dojemanje sebe $\mathrm{v}$ odnosu do njegovih družinskih članov ter odraža občutke primernosti, vrednosti in veljave v vlogi družinskega člana.
- Socialna samopodoba: preko te lestvice posameznik poda ocene svojih odnosov $\mathrm{z}$ drugimi $\mathrm{v}$ širšem družbenem okolju.

- Akademska samopodoba: ocena posameznikovih splošnih umskih sposobnosti in delovne učinkovitosti $\mathrm{v}$ primerjavi z drugimi.

- Celotna samopodoba: nanaša se na stopnjo samospoštovanja in način vrednotenja samega sebe.

- Konfliktnost odgovorov: rezultat odraža zmedenost, nasprotja in splošen konflikt $\mathrm{v}$ doživljanju sebe.

Naloga udeležencev je bila, da podajo odgovor na petstopenjski lestvici, pri čemer 1 pomeni "sploh ne drži" in 5 "povsem drži".

Ocena sebe. Predstavlja semantični diferencial, ki je sestavljen na osnovi sheme Realni Self - Želeni Self. Udeleženci so na 7-stopenjski lestvici označili svoj položaj

Tabela 3. Dvofaktorska rešitev analize glavnih komponent lestvice Ocena sebe

\begin{tabular}{lcc}
\hline & \multicolumn{2}{c}{ komponenta } \\
\cline { 2 - 3 } & $\begin{array}{c}\text { osebnostne } \\
\text { značilnosti }\end{array}$ & $\begin{array}{c}\text { socialne } \\
\text { značilnosti }\end{array}$ \\
\hline optimistična & $\mathbf{0 , 6 9}$ & 0,35 \\
samostojna & $\mathbf{0 , 4 3}$ & 0,38 \\
spretna & $\mathbf{0 , 7 1}$ & 0,28 \\
zdrava & 0,16 & $\mathbf{0 , 6 2}$ \\
inteligentna & $\mathbf{0 , 8 4}$ & 0,13 \\
prilagodljiva & $\mathbf{0 , 7 8}$ & $-0,05$ \\
živahna & $-0,44$ & $\mathbf{0 , 3 8}$ \\
družabna & $\mathbf{0 , 7 0}$ & 0,36 \\
zanimiva & $\mathbf{0 , 5 9}$ & 0,44 \\
fizično privlačna & 0,00 & $\mathbf{0 , 6 6}$ \\
sproščena & $\mathbf{0 , 6 3}$ & 0,40 \\
dobra & 0,27 & $\mathbf{0 , 7 6}$ \\
spoštovana & 0,25 & $\mathbf{0 , 8 0}$ \\
vztrajna & $\mathbf{0 , 7 6}$ & 0,11 \\
prijazna & 0,19 & $\mathbf{0 , 6 5}$ \\
\hline
\end{tabular}


med ekstremoma posamezne lastnosti. Nalogo smo sestavili sami, in sicer smo v semantični diferencial zajeli 15 lastnosti, ki smo jih izbrali na podlagi rezultatov študije T. Lamovec (1980) in v skladu s predhodnimi subjektivnimi izkušnjami z osebami iz primerjalnih skupin. Lastnosti se nanašajo na zaznavanje posameznikovega telesnega in socialnega Selfa ter na doživljanje splošne podobe. Vsak udeleženec je najprej podal oceno svojega realnega (kako se zaznava kot osebo), nato pa še želenega Selfa (kakšna oseba bi želel biti).

V danem navodilu smo udeležence zaprosili, naj ocenijo navedene osebnostne lastnosti glede na prepričanje o tem, v kolikšni meri so izražene pri njih. Ocene so podajali tako, da so obkrožili število na 7-stopenjski lestvici, kjer je ocena 4 predstavljala nevtralno točko, 1 in 7 pa sta bili skrajni oceni. Prosili smo jih, naj ocenjujejo hitro in po prvem vtisu.

Ker smo merski instrument oblikovali sami, smo izvedli analizo dimenzionalnosti, kjer smo skušali z analizo glavnih komponent preveriti, ali lahko postavke združimo in glede na njihove značilnosti obravnavamo z manjšim številom faktorjev. Ker smo vključili značilnosti, za katere smo predpostavljali, da opisujejo vsebinsko različna področja osebnosti, smo uporabili pravokotno rotacijo Varimax.

$\mathrm{Na}$ podlagi lastnih vrednosti grafa drobirja ter rezultatov vzporedne analize (Horn, 1965; Watkins, 2000) smo izločili tri komponente, ki so skupaj pojasnile $62,15 \%$ variance. Po pregledu trifaktorske rešitve smo ugotovili, da zadnja komponenta visoko nasičuje zgolj eno postavko, sočasno pa je bilo več postavk, ki so zmerno visoko korelirale $z$ več kot eno komponento. Iz tega razloga smo izključili zgolj dve komponenti, kar je rezultiralo v čistejši strukturi. Rezultate prikazuje tabela 3.

Obe komponenti skupaj pojasnjujeta $54,15 \%$ variance - od tega pojasni prva $31,13 \%$, druga pa $23,03 \%$ variance. Iz tabele 3 je razvidno, da prva komponenta nasičuje postavke, ki vsebinsko opisujejo pretežno posameznikove osebnostne značilnosti oz. sposobnosti in nakazujejo obliko notranje moči, ki je pomembna za posameznika kot osebo, zato smo jo poimenovali kot "osebnostne značilnosti”. Zdrava, živahna, fizično privlačna, dobra, spoštovana in prijazna pa so postavke, ki jih nasičuje druga komponenta. $\mathrm{V}$ primerjavi $\mathrm{z}$ lastnostmi prve komponente dojemamo te postavke kot lastnosti, ki so pretežno pomembne pri vzpostavljanju in vzdrževanju socialnih stikov ter nakazujejo družbeno veljavo, zato menimo, da tem lastnostim ustreza skupni naziv "socialne značilnosti”.

Izhajajoč iz rezultatov analize glavnih komponent smo $\mathrm{v}$ nadaljnjih analizah lestvici Realni in Idealni Self razdelili na dve podlestvici (osebnostne in socialne značilnosti). Pri vrednotenju smo upoštevali, da prva podlestvica, tj. Osebnostne značilnosti, vključuje 9

Tabela 4. Cronbachovi a koeficienti za posamezne lestvice TSCS-2 in semantičnega diferenciala realni Self - idealni Self v vseh skupinah udeležencev

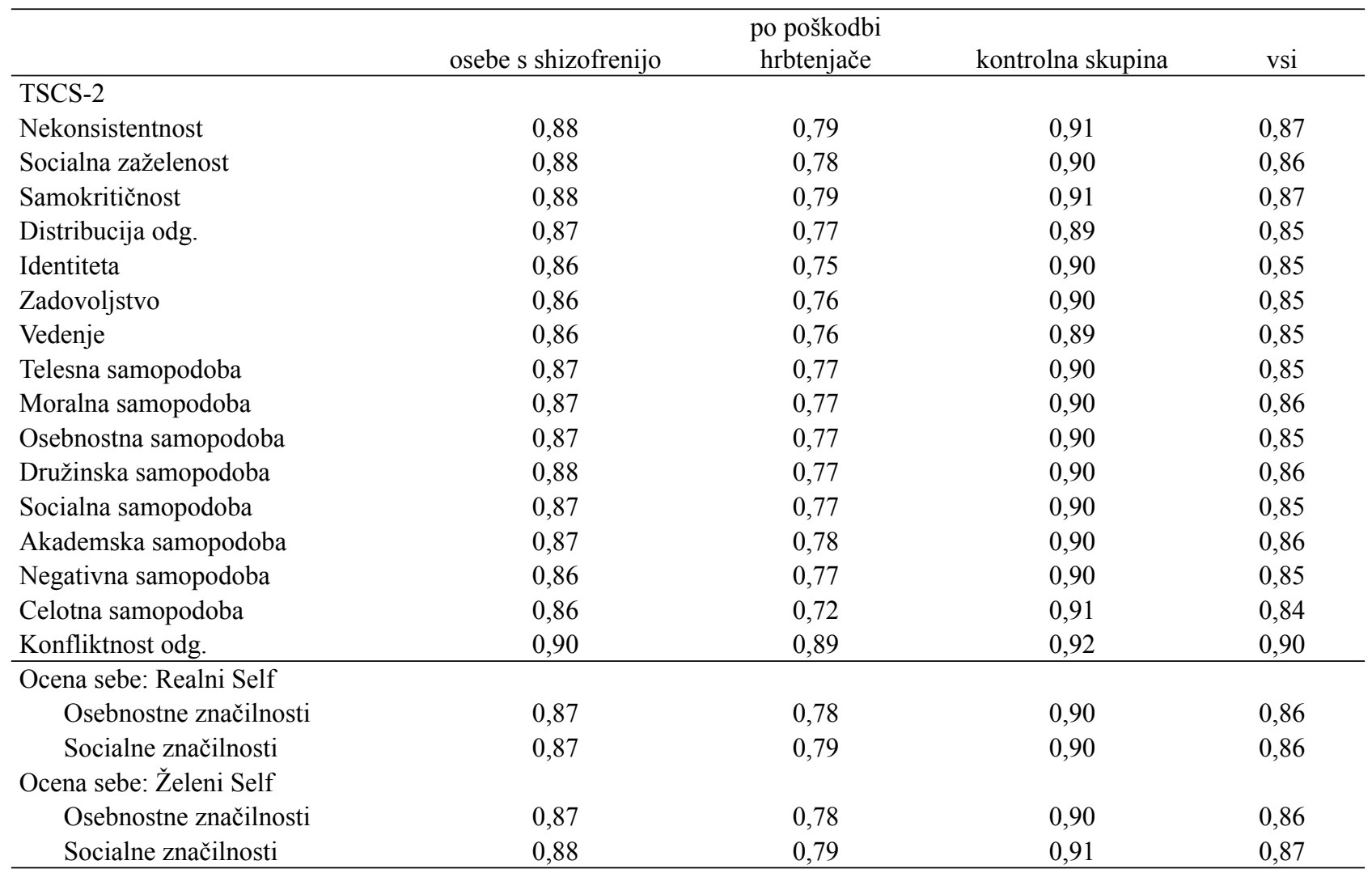

Opombe: $N$ (posamezne skupine) $=30$ 
postavk (optimistična, samostojna, okorna, inteligentna, prilagodljiva, družabna, zanimiva, sproščena in vztrajna), podlestvica Socialne značilnosti pa 6 postavk (zdrava, živahna, fizično privlačna, dobra, spoštovana ter prijazna). Rezultat posamezne podlestvice smo dobili tako, da smo ocene postavk posamezne lestvice med seboj sešteli. Pri vrednotenju smo upoštevali, da ima pozitivni ekstrem para višjo točkovno vrednost, zato smo najprej izvedli obrnjeno točkovanje negativnih pridevnikov.

Na tem mestu bi želeli opozoriti, da je bila uporabljena lestvica namenjena izključno za potrebe pričujoče študije ter za primerjavo majhnega vzorca dveh kliničnih populacij. Za možnost nadaljnje uporabe načrtujemo izvedbo konstruktne validacije na večjem vzorcu.

Kot smo že omenili, je bila v vzorec vključena klinična populacija. Iz tega razloga podajamo tudi izračune Cronbachovih koeficientov zanesljivosti $\alpha$ (tabela 4), ki smo jih izračunali tudi za lestvico TSC-2, ki se je v slovenskem prostoru sicer že izkazala kot zanesljiv instrument.

Cronbachovi $\alpha$-koeficienti notranje skladnosti za vse uporabljene lestvice (tabela 4) so bili v kontrolni skupini ter skupini oseb s shizofrenijo primerljivi in jih lahko po Greenu, Lissitzu in Mulaiku (1977) uvrstimo med koeficiente z dobro zanesljivostjo; v skupini udeležencev in udeleženk po nezgodni poškodbi hrbtenjače so koeficienti notranje skladnosti na vseh lestvicah nižji. Ti koeficienti se umeščajo en rang nižje, tj. v območje sprejemljive zanesljivosti. Primerljiva je zgolj stopnja zanesljivosti na lestvici, ki meri konfliktnost odgovorov.

\section{Postopek}

Raziskavo je odobrila Komisija Republike Slovenije za medicinsko etiko. Njena izvedba in zbiranje podatkov potekata od avgusta 2012 in sta še v teku. Predstavljeni so preliminarni rezultati študije 90-ih udeležencev in udeleženk, ki temeljijo na izpolnjenih vprašalnikih tipa papir-svinčnik. Z vsakim udeležencem oz. udeleženko smo se osebno srečali ter podali enaka navodila. Izpolnjevanje vprašalnikov je pri vsaki osebi trajalo približno 20 minut. Za analizo podatkov smo uporabili statistični program PASW Statistics 18.

\section{Rezultati}

Pred obdelavo podatkov smo izvedli KolmogorovSmirnov test za porazdelitev dosežkov vseh skupin udeležencev. Od normalne porazdelitve so statistično pomembno odstopale le porazdelitve sledečih podlestvic: nekonsistentnost $(z=1,69 ; p=0,01)$, konfliktnost odgovorov $(z=1,65 ; p=0,01)$ ter osebnostne $(z=1,95 ; p=0,00)$ in socialne značilnosti $(z=1,59 ; p=0,01)$ želenega Selfa. Rezultate testa smo za vsako lestvico posebej podkrepili tudi z izrisom histogramov s krivuljo normalne porazdelitve. Ker nobena porazdelitev ni bistveno odstopala od normalne krivulje, smo neparametrične teste v primerih, ko nismo kršili drugih pomembnih predpostavk uporabljenih postopkov, dopolnili s parametričnimi. Preverili smo tudi porazdelitev demografskih spremenljivk starosti in trajanja izobraževanja $\mathrm{v}$ posamezni skupini udeležencev in udeleženk. Izkazalo se je, da se njuna porazdelitev v vseh skupinah zadovoljivo prilega normalni porazdelitvi.

Osrednji problem naše študije je predstavljala primerjava značilnosti doživljanja sebe med osebami s shizofrenijo in tistih po nezgodni poškodbi hrbtenjače, zato nas je najprej zanimalo, ali med tema skupinama oseb obstajajo razlike $\mathrm{v}$ povprečnih dosežkih na posameznih lestvicah doživljanja sebe. Najprej smo izvedli enosmerno ANOVO za neponovljene meritve, kjer so rezultati Levenovega testa pokazali, da so na mnogih uporabljenih letvicah variance med skupinami nehomogene. Zaradi kršitev predpostavke o homogenosti varianc smo $\mathrm{V}$ nadaljnji analizi izbrali neparametrične postopke obdelave podatkov.

Z neparametričnim Kruskal-Wallisovim testom smo primerjali mere srednje vrednosti (mediane) na posameznih lestvicah Tennesseejske lestvice koncepta sebe ter ocen realnega in želenega Selfa, ki smo ju dobili prek semantičnega diferenciala. Da bi preverili odstopanja med ocenami realnega in želenega Selfa, smo ne obeh podlestvicah izračunali razliko med njima. Rezultati so zbrani v tabeli 5 .

Razvidno je, da so $\mathrm{v}$ vseh primerih statistično pomembnih razlik imeli najnižje povprečne dosežke udeleženci in udeleženke, ki so oboleli za shizofrenijo. Osebe s shizofrenijo so torej podajale bolj socialno zaželene odgovore. V splošnem so se izkazali kot nezadovoljni s svojo identiteto ter splošno samopodobo. Nimajo oblikovanega občutka lastne vrednosti in se dojemajo z bolj negativnega vidika, kar se ne nazadnje odraža tudi v ocenah realnega Selfa, ki so v primerjavi z ocenami v obeh preostalih skupinah pomembno nižje. Prav tako pomembno odstopajo tudi na socialnem področju, in sicer tako na področju vključenosti v družinsko kot tudi v širše socialno okolje. Ocene nakazujejo nesprejetost, težave $\mathrm{v}$ vzpostavljanju ter vzdrževanju odnosov in $\mathrm{v}$ pomanjkljivosti komunikacijskih veščin.

Čeprav se udeleženci in udeleženke različnih skupin na lestvici, ki meri nekonsistentnost odgovarjanja, ne razlikujejo statistično pomembno, lahko razberemo, da je le-ta $\mathrm{v}$ primerjalnih skupinah nekoliko višja, kot $\mathrm{v}$ kontrolni skupini. Nadalje lahko opazimo, da je najvišja stopnja samokritičnosti prisotna med udeleženci in udeleženkami po nezgodni poškodbi hrbtenjače, kjer so tudi največje in statistično pomembne razlike $\mathrm{v}$ ocenah socialnih značilnosti realnega in želenega Selfa na lestvici Ocena sebe. V tej skupini udeležencev in udeleženk pa so sočasno prisotne tudi najnižje ocene akademske samopodobe. 
Tabela 5. Rezultati Kruskal-Wallisovega testa za posamezne podlestvice TSCS-2 in za lestvico Ocena sebe

\begin{tabular}{|c|c|c|c|c|c|}
\hline & \multicolumn{3}{|c|}{ povprečni rang } & \multirow[b]{2}{*}{$\chi^{2}$} & \multirow[b]{2}{*}{$p$} \\
\hline & osebe s shizofrenijo & $\begin{array}{l}\text { po poškodbi } \\
\text { hrbtenjače }\end{array}$ & $\begin{array}{l}\text { kontrolna } \\
\text { skupina }\end{array}$ & & \\
\hline \multicolumn{6}{|l|}{ TCS-2 } \\
\hline Nekonsistentnost & 48,92 & 48,45 & 39,13 & 2,72 & 0,26 \\
\hline Socialna zaželenost & 35,08 & 46,73 & 54,68 & 8,59 & 0,01 \\
\hline Samokritičnost & 41,97 & 53,73 & 40,80 & 4,52 & 0,10 \\
\hline Distribucija odg. & 42,35 & 49,67 & 44,48 & 1,25 & 0,53 \\
\hline Identiteta & 29,48 & 50,00 & 57,02 & 18,02 & 0,00 \\
\hline Zadovoljstvo & 36,80 & 48,75 & 50,95 & 5,11 & 0,08 \\
\hline Vedenje & 34,57 & 48,37 & 53,57 & 8,49 & 0,01 \\
\hline Telesna samopodoba & 36,82 & 46,23 & 53,45 & 6,13 & 0,05 \\
\hline Moralna samopodoba & 39,38 & 46,45 & 50,67 & 2,87 & 0,24 \\
\hline Osebnostna samopodoba & 40,32 & 45,28 & 50,90 & 2,48 & 0,29 \\
\hline Družinska samopodoba & 26,10 & 51,58 & 58,72 & 25,96 & 0,00 \\
\hline Socialna samopodoba & 35,63 & 51,45 & 49,42 & 6,53 & 0,04 \\
\hline Akademska samopodoba & 42,37 & 39,87 & 54,27 & 5,22 & 0,07 \\
\hline Celotna samopodoba & 33,80 & 47,52 & 55,18 & 10,32 & 0,01 \\
\hline Konfliktnost odg. & 50,50 & 42,03 & 43,97 & 1,73 & 0,42 \\
\hline \multicolumn{6}{|l|}{ Ocena sebe: Realni jaz } \\
\hline Osebnostne značilnosti & 37,35 & 47,87 & 51,28 & 4,65 & 0,10 \\
\hline Socialne značilnosti & 27,40 & 55,58 & 53,52 & 21,78 & 0,00 \\
\hline \multicolumn{6}{|l|}{ Ocena sebe: Želeni jaz } \\
\hline Osebnostne značilnosti & 38,52 & 45,90 & 52,08 & 4,09 & 0,13 \\
\hline Socialne značilnosti & 39,55 & 48,68 & 48,27 & 2,36 & 0,31 \\
\hline Razlika os. značilnosti & 40,33 & 51,28 & 44,88 & 2,67 & 0,26 \\
\hline Razlika soc. značilnosti & 29,80 & 53,82 & 52,88 & 16,38 & 0,00 \\
\hline
\end{tabular}

Opombe: $N=90 ; d f=2$.

Z namenom, da bi dobili natančnejši vpogled, med katerimi skupinami udeležencev in udeleženk obstajajo pomembne razlike na posamezni lestvici, smo izvedli Mann-Whitneyjeve teste.

Rezultati v tabeli 6 kažejo, da izstopajo statistično pomembne razlike tako na lestvici TSC-2 kot tudi na lestvici Ocena sebe predvsem med skupino oseb $\mathrm{s}$ shizofrenijo in med kontrolno skupino. Povprečni rangi obeh skupin udeležencev se statistično pomembno razlikujejo v ocenah telesne, socialne, družinske in celotne samopodobe; udeleženci s shizofrenijo so v vseh primerih podali nižje ocene. Poleg tega osebe s shizofrenijo v primerjavi s kontrolno skupino zaznavajo svoje vedenje in celotno identiteto (kot) bolj negativno. Analiza socialne zaželenosti odgovorov je pokazala, da osebe s shizofrenijo v večji meri podajajo socialno zaželene odgovore, saj so bile njihove ocene glede na kontrolno skupino pomembno višje. Nadalje vidimo, da osebe s shizofrenijo pomembno odstopajo $\mathrm{v}$ ocenah Realnega jaza, kjer se ponovno opisujejo $\mathrm{s}$ statistično pomembno nižjimi ocenami glede na udeležence iz kontrolne skupine, sočasno pa imajo oblikovane nižje ideale glede svojih osebnostnih značilnosti.

Po drugi strani ugotavljamo med kontrolno skupino in skupino oseb po nezgodni poškodbi hrbtenjače zgolj eno statistično pomembno razliko, ki je opazna v pomembno nižjih samoocenah oseb po nezgodni poškodbi hrbtenjače na področju akademske samopodobe.

Na koncu smo znotraj posameznih skupin udeležencev preverili učinek demografskih spremenljivk (spol, starost, trajanje izobraževanja) na dosežke vseh uporabljenih lestvic. Rezultati testiranj so pokazali, da so prisotne razlike v podajanju odgovorov le glede na spol udeležencev. Rezultati Mann-Whitneyjevega testa so pokazali, da v skupini oseb s shizofrenijo moški v večji meri podajajo socialno zaželene odgovore $(Z=2,21 ; p=0,03 ; r=0,40$; povprečni rang ${ }_{\text {moški }}=19,03$; povprečni rang $_{\text {žnnke }}=11,97$ ), hkrati pa imajo izoblikovano boljšo identiteto o samem sebi, kar pomeni, da so $\mathrm{s}$ samim seboj $\mathrm{V}$ primerjavi $\mathrm{z}$ ženskami bolj zadovoljni $(Z=2,41 ; p=0,02 ; r=0,44$; povprečni rang $\operatorname{moški}_{1}=19,37$; povprečni rang $\left._{\text {ženske }}=11,63\right)$. Razlike glede na spol so se pokazale tudi $\mathrm{v}$ kontrolni skupini, kjer imajo moški prav tako izoblikovano boljšo identiteto $(Z=-1,96 ; p=0,05 ; r=0,36$; povprečni rang moški $=18,63$; povprečni rang $_{\text {ženske }}=12,37$ ). Prav tako so $\mathrm{V}$ kontrolni skupini moški udeleženci tisti, ki v primerjavi z ženskami svojo telesno samopodobo ocenjujejo kot pomembno višjo $(Z=-2,35 ; p=0,02 ; r=0,43$; povprečni $\operatorname{rang}_{\text {moški }}=19,27$; povprečni rang $_{\text {žnnse }}=11,73$ ). Analiza odgovorov udeležencev glede na njihov zakonski stan ni pokazala pomembnih razlik. 
Tabela 6. Statistično pomembne razlike (Mann-Whitneyev test) med skupinama udeležencev na vseh uporabljenih lestvicah

\begin{tabular}{|c|c|c|c|c|c|c|}
\hline \multirow[b]{2}{*}{ področje } & \multicolumn{3}{|c|}{ povprečni rang } & \multirow[b]{2}{*}{$Z$} & \multirow[b]{2}{*}{$p$} & \multirow[b]{2}{*}{$r$} \\
\hline & shizofrenija & paraplegija & kontrolna skupina & & & \\
\hline \multicolumn{7}{|l|}{ TCS-2 } \\
\hline Telesna samopodoba & 25,13 & / & 35,87 & $-2,38$ & 0,02 & 0,31 \\
\hline \multirow[t]{2}{*}{ Socialna samopodoba } & 25,37 & / & 35,63 & $-2,28$ & 0,03 & 0,29 \\
\hline & 25,77 & 35,23 & / & $-2,10$ & 0,04 & 0,27 \\
\hline \multirow[t]{2}{*}{ Družinska samopodoba } & 19,32 & / & 41,68 & $-4,97$ & $<0,01$ & 0,64 \\
\hline & 22,28 & 38,72 & / & $-3,65$ & $<0,01$ & 0,47 \\
\hline \multirow[t]{2}{*}{ Celotna samopodoba } & 23,30 & / & 37,70 & $-3,20$ & 0,00 & 0,41 \\
\hline & 26,00 & 35,00 & / & $-2,00$ & 0,05 & 0,26 \\
\hline \multirow[t]{2}{*}{ Vedenje } & 24,08 & l & 36,92 & 2,85 & 0,00 & 0,37 \\
\hline & 25,98 & 35,02 & / & $-2,01$ & 0,05 & 0,26 \\
\hline \multirow[t]{2}{*}{ Identiteta } & 20,77 & / & 35,32 & $-4,32$ & $<0,01$ & 0,56 \\
\hline & 24,22 & 36,78 & l & $-2,79$ & 0,01 & 0,36 \\
\hline Socialna zaželenost & 33,37 & / & 27,63 & $-2,91$ & 0,00 & 0,38 \\
\hline Akademska samopodoba & / & 25,48 & 35,52 & $-2,23$ & 0,03 & 0,29 \\
\hline \multicolumn{7}{|l|}{ Ocena sebe: Realni jaz } \\
\hline Osebnostne značilnosti & 25,55 & / & 35,45 & $-2,20$ & 0,03 & 0,28 \\
\hline \multirow[t]{2}{*}{ Socialne značilnosti } & 21,98 & l & 39,02 & $-3,79$ & $<0,01$ & 0,49 \\
\hline & 20,92 & 40,08 & / & $-4,24$ & $<0,01$ & 0,54 \\
\hline \multicolumn{7}{|l|}{ Ocena sebe: Želeni jaz } \\
\hline Osebnostne značilnosti & 25,87 & & 35,13 & $-2,06$ & 0,04 & 0,27 \\
\hline
\end{tabular}

Opombe: $N$ (posamezne skupine) $=30$

\section{Razprava}

Osnovni problem pričujoče raziskave je predstavljala primerjava značilnosti doživljanja sebe pri osebah $\mathrm{s}$ shizofrenijo in pri tistih po nezgodni poškodbi hrbtenjače. Med obema primerjalnima skupinama ter kontrolno skupino posameznikov brez predhodno diagnosticirane nevrološke, duševne ali druge kronične somatske bolezni smo pričakovali pomembne razlike na različnih področjih doživljanja sebe. Ključna odstopanja smo predvidevali predvsem na področju doživljanja telesnega in socialnega Selfa pri udeležencih iz obeh primerjalnih skupin; pri osebah s shizofrenijo trend pomembno bolj negativnega doživljanja sebe; pri tistih po poškodbi hrbtenjače pa obrambno-varovalno naravnanost.

Nekatere razlike med odgovori primerjalnih skupin so se pokazale že ob preverjanju zanesljivosti, kjer so udeleženci po nezgodni poškodbi hrbtenjače podajali manj zanesljive odgovore, kar lahko povežemo z dejstvom, da so ti udeleženci $v$ povprečju dosegali najvišje rezultate na lestvici Distribucija odgovorov. Čeprav razlika ni statistično pomembna, je po kriterijih TSCS-2 surova vrednost rezultatov že na meji, ki nakazuje tendenco $\mathrm{k}$ podajanju ekstremnih odgovorov (v odgovorih udeležencev so v večji meri prisotni odgovori 1 in 5; Fits in Waren, 1996). Tovrstni odgovori služijo kot potrjevanje pozitivnega Selfa in s tem lažne samopodobe (Fits in Waren, 1996). Omenjeno spoznanje podpira teorijo, po kateri so posamezniki, ki imajo na kakršenkoli način spremenjeno svojo telesno shemo, bodisi oteženo ali onemogočeno njeno normalno delovanje, usmerjeni $\mathrm{v}$ idealizacijo le-te (Richards idr., 2010). Tudi Brejc (2004) ter Richards s sodelavci (2010) pišejo, da so osebe po nezgodni poškodbi hrbtenjače podvržene $\mathrm{k}$ potrjevanju pozitivne samopodobe, kar zmanjšuje grožnjo stopnji njihovega zadovoljstva s samim seboj, predstavlja obrambnovarovalno delovanje ter lajša proces sprejemanja nove podobe. Dobljeni rezultati ne podpirajo podane teorije, po kateri naj bi bil zaradi težnje $\mathrm{k}$ potrjevanju pozitivne samopodobe realni Self zelo blizu želenemu, razlika med njima pa zatorej majhna (Geyh idr., 2012). Odstopanje v ocenah socialnih značilnosti realnega in želenega Selfa se je namreč med skupinami izkazalo kot statistično pomembno, in je najvišje prav v skupini oseb po nezgodni poškodbi hrbtenjače. To pomeni, da si te osebe želijo več sprememb na ravni socialnih značilnosti. Ob razmišljanju, zakaj tovrstne razlike prav v tej skupini, smo se oprli na študije (npr. DeSanto-Madeya, 2006a, 2006b; Westie, 1987), ki opisujejo proces spoprijemanja z novo telesno podobo, tj. z novim Selfom, ki močno spominja na potek žalovanja ob izgubi bližnjega. Skozi ta proces postanejo sprva nekoliko odmaknjeni od družbenega življenja, postopoma pa začnejo graditi na socialni samopodobi, prek katere skušajo kompenzirati zmanjšano zmožnost delovanja na področju telesnih zmogljivosti (Westie, 1987). Glede na to, da je pri naših udeležencih od poškodbe v povprečju preteklo že skoraj 18 let, menimo, da lahko želje po pomembnih spremembah na področju socialnih značilnosti predstavljajo način kompenzacije. Omenjeno odstopanje ocen med realnim in želenim Selfom je na 
nek način $\mathrm{v}$ nasprotju $\mathrm{z}$ oceno celotne samopodobe, $\mathrm{ki}$ so jo udeleženci te skupine ocenili kot zadovoljivo, saj njihove ocene glede na ocene kontrolne skupine ne odstopajo statistično pomembno. Ponovno je bilo prisotno nasprotujoče si podajanje odgovorov. Slednje na nek način nakazuje že omenjena znižana zanesljivost celotne testne baterije; to pa je lahko povezano z delovanjem obrambnih mehanizmov kot posledica neuspešno izpeljanega procesa žalovanja ter posledično $\mathrm{s}$ strmenjem $\mathrm{k}$ pozitivnemu potrjevanju sebe.

Nadalje rezultati primerjave podatkov s KruskalWallisovim in Mann-Whitneyjevim testom kažejo na prisotnost statistično pomembnih razlik pretežno med skupino oseb s shizofrenijo in kontrolno skupino. Tako kot ugotavljajo v številnih predhodnih študijah (Conway, 2005; Fitts in Warren, 1996; Yanos idr., 2010), imajo namreč bolniki zmotnjami shizofrenega spektra o različnih vidikih sebe (npr. telesni, socialni, akademski, moralni Self) bolj negativno podobo, kar kaže na pomembno različno doživljanje sebe glede na zdravo skupino oseb (Benedik, 2000a; Raffard idr., 2009; Sass in Parnas, 2003; Smrdu, 2013; Yanos idr., 2010). Rezultati naše študije kažejo, da osebe s shizofrenijo v primerjavi z ostalima skupinama pomembno nižje vrednotijo družinsko, telesno ter socialno komponento Selfa; posledično pa je pomembno nižja tudi ocena celotne samopodobe, saj se vse tri z njo visoko in pomembno povezujejo. Nižje ocene na področju družinske kot tudi socialne samopodobe podpirajo teorijo, po kateri osebe s shizofrenijo nimajo natančne in stalne predstave o socialnem vidiku svojega Selfa (Combs idr., 2012; Lysaker idr., 2005), kar sovpada tudi s primanjkljaji na področju socialnih interakcij (Lysaker, Johannesen in Lysaker, 2005; Raffard idr., 2009; Sass in Parnas, 2003). Omenjena oškodovanost na področju socialnega življenja vodi do pomanjkljivih zmožnosti preklapljanja med različnimi področji sebe (Bak, 1954; Freeman, 1973; Pao, 1979; vse v Lysaker idr., 2005), kar se kaže v pomembno nizki, celo negativni samopodobi, ki jo $\mathrm{v}$ skupini oseb s shizofrenijo ugotavljamo tudi v našem vzorcu udeležencev. Po Bleulerju (1911; v Raffard idr., 2009) naj bi pri shizofreniji prav motnja kontinuitete Selfa, ki se kaže preko notranjega razpada enotnosti, predstavljala osrednjo prizadetost oz. odstopanje od normalnosti.

Glede na podano teorijo bi pričakovali, da se bodo osebe s shizofrenijo pomembno nižje ocenjevale tudi na področju akademske samopodobe, česar pa rezultati niso podprli. Ugotovili smo prav nasprotno, saj so osebe po nezgodni poškodbi hrbtenjače $\mathrm{v}$ primerjavi $\mathrm{z}$ obema drugima skupinama udeležencev na tej lestvici podajale najnižje ocene. Morda bi se lahko ob tem oprli na teorijo, po kateri so socialne interakcije tiste, ki krepijo posameznikov Self (DeSanto-Madeya, 2006a; Lysaker idr., 2005), zaradi česar utegnejo biti osebe po nezgodni poškodbi hrbtenjače pod delovanjem obrambno-varovalnih mehanizmov, med katerimi bi lahko izpostavili kompenzacijo. Slednja vodi v intenzivnejše socialno udejstvovanje, kar podpira tudi dejstvo, da osebe po nezgodni poškodbi hrbtenjače glede na kontrolno skupino svojega družinskega in socialnega
Selfa ne dojemajo kot pomembno drugačnega, hkrati pa si prizadevajo za čim višje izražene značilnosti socialnega Selfa, kjer si želijo največjih sprememb. Energijo za ohranjanje pozitivne samopodobe zato verjetno usmerjajo $\mathrm{v}$ socialno udejstvovanje in ne toliko $\mathrm{v}$ akademsko, kjer so po navedbah literature (Murray idr., 2007) zaradi višje izražene impulzivnosti ter težav s koncentracijo slabši že pred poškodbo.

$\mathrm{Na}$ podlagi rezultatov bi lahko zaključili, da je doživljanje sebe v skladu z našimi pričakovanji pri obeh primerjalnihskupinah specifično-priosebah s shizofrenijo je vrednotenje sebe pomembno nizko (celo negativno); pri osebah po nezgodni poškodbi hrbtenjače pa idealizirano, pod vplivom obrambno-varovalnega vedenja in zato naravnano k podajanju socialno zaželenih odgovorov, ki omogočajo potrjevanje pozitivne samopodobe.

Menimo, da so izsledki študije pomembni predvsem za usmerjanje psihološkega dela s predstavniki obeh populacij. Pri osebah s shizofrenijo bi bilo v procesu rehabilitacije morda zaželeno še dodatno poudariti pomen zaznavanja sebe na različnih področjih ter njegovega vpliva na posameznikovo delovanje. Po dosedanjih izkušnjah je poudarek predvsem na prizadevanjih za čim bolj uspešno vrnitev v socialno okolje (Haddock in Spaulding, 2011; Pollard in Kennedy, 2007), pomen doživljanja sebe pa je morda nekoliko zanemarjen. Osebe po nezgodni poškodbi hrbtenjače bi morali usmerjati k nadomeščanju manj zrelih oblik obrambno-varovalnega vedenja $\mathrm{z}$ bolj zrelimi ter $\mathrm{s}$ tem k realnejšemu doživljanju sebe. V okviru tega bi lahko predstavili različna področja doživljanja sebe - telesno, socialno, družinsko, osebno, moralno in akademsko, ter njihove medsebojne povezave in prepletanja, predvsem pomen potrjevanja lažne pozitivne samopodobe.

Skozi izkušnje izvajanja raziskave pa bi želeli opozoriti na nekatere pomanjkljivosti ter predlagati spremembe, skozi katere bi lahko študijo izboljšali. Ob morebitni ponovitvi bi bilo vsekakor zaželeno vključiti večji vzorec udeležencev in udeleženk. Zanimiva bi bila vzdolžna študija, v kateri bi preverjali samoocene samopodobe v različnih časovnih intervalih pri istih osebah, kar bi nam omogočilo natančnejši vpogled $\mathrm{v}$ morebitni proces spreminjanja samopodobe pri posameznikih $\mathrm{z}$ različno patologijo. Prav tako bi bilo zaželeno vzorec povečati $s$ še več primerjalnimi skupinami, ki bi pokrivale različne patologije (več skupin oseb z različnimi duševnimi motnjami ter specifičnimi zmanjšanimi zmožnostmi telesnega delovanja). Na podlagi njihovih rezultatov bi lahko primerjali razlike v doživljanju sebe med skupinami in znotraj posamezne podskupine (duševne motnje, gibalno ovirana invalidnost). Prav tako bi natančna razmejitev obstoječih, trenutno zelo »širokih« skupin bolnikov omogočila sestavo bolj homogenega vzorca ter $\mathrm{s}$ tem pomembno doprinesla $\mathrm{k}$ direktni in veljavnejši primerjavi. Glede na literaturo, predstavljeno v uvodu (Wortman in Silver, 1989), bi bilo pri osebah po nezgodni poškodbi hrbtenjače zanimivo natančneje proučiti proces njihovega žalovanja ter osebnostno naravnanost pacienta pred nesrečo (posamezniki $\mathrm{z}$ negodnimi poškodbami 
hrbtenjače se lahko nagibajo k tveganemu načinu življenja, kjer je telo in njegova funkcija daleč najbolj v ospredju in je zato proces zanikanja podaljšan globoko $\mathrm{v}$ obdobje procesa okrevanja po nezgodi).

\section{Literatura}

Amiram, B. V. in Selzer, M. L. (1975). Desirable versus undesirable life events: Their relationship to stress and mental distress. Journal of Personality and Social Psychology, 32(2), 329-337.

Anderson, K. D. (2004). Targeting Recovery: Priorities of the Spinal Cord-Injured Population. Journal of Neurotrauma, 21(10), 1371-1383.

Benedik, E. (2000a). Doživljanje samega sebe in pomembnih drugih oseb psihiatričnih bolnikov. [Experience of oneself and other persons relevant psychiatric patients] (Neobjavljena doktorska disertacija). Filozofska fakulteta, Univerza v Ljubljani, Slovenija.

Benedik, E. (2000b). Kako psihiatrični bolniki doživljajo samega sebe in bližnje osebe [How psychiatric patients experience the self and significant]. Anthropos, 11(34), 51-62.

Benedik, E. (2001). Vprašalnik doživljanja sebe in drugih ljudi [Sensing of self and other people questionnaire]. Psihološka obzorja, 10(1), 27-48.

Bentall, R. P., Kinderman, P. in Kaney, S. (1994). The self, attributional processes and abnormal beliefs: Towards a model of persecutory delusions. Behaviour Research and Therapy, 32, 331-341.

Brejc, T. (2004). Prispevki k rehabilitacijski psihologiji [Contributions to rehabilitation psychology]. Ljubljana: Inštitut Republike Slovenije za rehabilitacijo.

Brejc, T. in Stante, M. (1983, november). Tennesseeska lestvicakonceptajaza. V J. Gregorač(ur.). Posvetovanje psihologov Slovenije. Predstavitev na Posvetovanju psihologov Slovenije,, Portorož, Slovenija (str. 1-4). Ljubljana: Društvo psihologov SR Slovenije.

Chau, L., Hegedus, L., Praamsma, M., Smith, K., Tsukada, M., Yoshida, K. in Renwick, R. (2008). Women living with a spinal cord injury: Perceptions about their changed bodies. Qualitative Health Research, 18(2), 209-221.

Chronister, J. in Johnson, E. (2009). Multiculturalism and adjustment to disability. V F. Chan, E. S. Cardoso in J. A. Chronister (ur.), Understanding psychosocial adjustment to chronic illness and disability (str. 479520). New York: Springer.

Combs, D., Mueser, K. T. in Gutierrez, M. M. (2012). Schizophrenia. V M. Hersen in D. Beidel (ur.), Adult psychopathology and diagnosis (6. izd.) (str. 261-315). New York: Wiley.

Conway, M. A. (2005). Memory ant the self. Journal of Memory and Language, 53, 594-628.
DeSanto-Madeya, S. A. (2006a). A secondary analysis of the meaning of living with spinal cord injury using Roy's Adaptation Model. Nursing Science Quarterly, 19(3), 240-246.

DeSanto-Madeya, S. A. (2006b). The meaning of living with spinal cord injury 5 to 10 years after the injury. Western Journal of Nursing Research, 28(3), 265-289.

Drench, M. E. (1994). Changes in body image secondary to disease and injury. Rehabilitation Nursing, 19, $31-36$.

Fitts, W. H. in Warren, W. L. (1996). Tennessee SelfConcept Scale (TSCS: 2): Second edition manual. Los Angeles: Western psychological services.

Frank, R. G., Rosenthal, M. in Caplan, B. (2009). Handbook of rehabilitation Psychology (2. izd.). Washington: American Psychological Association.

Geyh, S., Nick, E., Stirnimann, D., Ehrat, S., Michel, F., Peter, C. in Lude, P. (2012). Self-efficacy and self-esteem as predictors of participation in spinal cord injury - an ICF-based study. Spinal Cord, 50, 699-706.

Green, S. B., Lissitz, R.W. in Mulaik, S. A. (1977). Limitations of coefficient alpha as an index of test unidimensionality. Educational and Psychological Measurement, 37, 827-838.

Groznik, M. (1999). Oviranosti in potrebe po rehabilitaciji ambulantnih bolnikov s shizofrenijo. Medicinski razgledi, 38, 485-486.

Haddock, G. in Spaulding, W. (2011). Psychological treatment of psychosis. V D. R. Weinberger in P. J. Harrison (ur.), Schizophrenia (3. izd.) (str. 666-686). New York: Willey Blackwell.

Horn, J. L. (1965). A rationale and test for the number of factors in factor analysis. Psychometrika, 30, $179-185$.

Horvat, B. (2012). How do people after spinal cord injury experience themselves? V N. Škof (ur.), Horizons of otherness (str. 93-104). Ljubljana: Bori.

Howe, M. L., Courage, M. L. in Edison, S. C. (2003). When autobiographical memory begins. Developmental Review, 23, 471-494.

Hughes, B. (2002). Disability and the body. V C. Banes, M. Oliver in L. Barton (ur.), Disability studies today (str. 58-76). Cambridge: Polity Press.

Jaramillo, P., Fuentes, I. I. in Ruiz, J. C. (2009). Cognition, social cognition and social functioning in schizophrenia. Psychology, Society and Education, 1(1), 13-24.

Kobal Grum, D. (2000). Temeljni vidiki samopodobe (1. izd.). Ljubljana: Pedagoški inštitut.

Lamovec, T. (1980). Eksperimentalni priročnik iz psihologije motivacije, emocij, osebnosti in učenja. Ljubljana: Filozofska fakulteta.

Lysaker, P. H., Johannesen, J. K. in Lysaker, J. T. (2005). Schizophrenia and the experience of intersubjectivity as treat. Phenomenology and the Cognitive Sciences, 4, 335-352. 
McConnell, A. R. (2011). The multiple self-aspects framework: Self-concept representation and its implications. Personality and Social Psychology Review, 15(1), 3-27.

Miller Smedema, S., Bakken-Gillen, S. K. in Dalton, J. (2009). Psychosocial adaptation to chronic illness and disability: Models and measurement. V F. Chan, E. Da Silva Cardoso in J. A. Chronister (ur.), Understanding psychosocial adjustment to chronic illness and disability (str. 51-68). New York: Springer.

Murray, R. F., Asghari, A., Egorov, D. D., Rutkowski, S. B., Siddall, P. J., Soden, R. J. in Ruff, R. (2007). Impact of spinal cord injury on self-perceived preand postmorbid cognitive, emotional and physical functioning. Spinal Cord, 45, 429-436.

Omolayo, B. (2009). Self-esteem and self-motivational needs of disabled and non-disabled: A comparative analysis. Journal of Alternative Perspectives in the Social Sciences, 1(2), 449-458.

Pollard, C. in Kennedy, P. (2007). A longitudinal analysis of emotional impact, coping strategies and posttraumatic psychological growth following spinal cord injury: A 10-year review. British Journal of Health Psychology, 12, 347-362.

Raffard, S., D'Argembeau, A., Lardi, C., Bayard, S., Boulenger, J. P. in Van Der Linden, M. (2009). Exploring self-defining memories in schizophrenia. Memory, 17(1), 26-38.

Rakovec-Felser, Z. (2009). Psihologija telesnega bolnika in njegovega okolja. Maribor: Pivec.

Richards, J. S., Kewman, D. G., Richardson, E. in Kennedy, P. (2010). Spinal cord injury. V Frank, R. G., Rosenthal, M. and Caplan, B. (ur.), Handbook of rehabilitation psychology (str. 9-29). Washington, ZDA: American Psychological Association.

Sass, L. A. in Parnas, J. (2003). Schizophrenia, consciousness and the self. Schizophrenia Bulletin, 29(3), 427-444.

Sheldon, A. P., Renwick, R. in Yoshida, K. K. (2011). Exploring body image and self-concept of men with acquired spinal cord injuries. American Journal of Men's Health, 5(4), 306-317.

Smrdu, M. (2013). Ocenjevanje psihotičnih motenj. V R. Masten in M. Smrdu (ur.), Klinična psihologija (str. 245-273). Ljubljana: Filozofska fakulteta.

Taleporos, G. in McCabe, M. P. (2002). Body image and physical disability: Personal perspectives. Social Science and Medicine, 54, 971-980.

Yanos, P. T., Roe, D. in Lysaker, P. H. (2010). The impact of illness identity on recovery from severe mental illness. American Journal of Psychiatric Rehabilitation, 13, 73-93.

Walker, E. in Tessner, K. (2008). Schizophrenia. Association of Psychological Science, 3(1), 30-37.

Watkins, M. W. (2000). Monte Carlo PCA for parallel analysis [programska oprema]. State College, PA, ZDA: Ed \& Psych Associates.
Westie, K. S. (1987). Psychological aspects of spinal cord injury. Clinical Prosthetic and Orthotics, 11(4), 225-229.

WHO (1993). The ICD-10 Classification of Mental and Behavioural Disorders - Diagnostic criteria for research. Ženeva.

Wortman, C. B. in Silver, R. C. (1989). The myths of coping with loss. Journal of Consulting and Clinical Psychology, 57(3), 349-357.

Zissi, A., Barry, M. M. in Cochrane, R. (1998). A mediational model of quality of life for individuals with severe mental health problems. Psychological Medicine, 28, 1221-1230. 